\title{
Austroeupatorium inulifolium invasion alters soil seed bank in anthropogenic grassland: A case study from Sri Lanka
}

\author{
I.P.K. Piyasinghe ${ }^{1,2, *}$, J. Gunatilake ${ }^{3}$ and H.M.S.P. Madawala ${ }^{1}$ \\ ${ }^{1}$ Department of Botany, Faculty of Science, University of Peradeniya, Sri Lanka \\ ${ }^{2}$ Postgraduate Institute of Science, Peradeniya, Sri Lanka \\ ${ }^{3}$ Department of Geology, Faculty of Science, University of Peradeniya, Sri Lanka
}

Received: 09/03/2017; Accepted: 17/05/2017

\begin{abstract}
Austroeupatorium inulifolium is aggressively invading many land use types in the Knuckles Conservation Area (KCA) in Sri Lanka. The Cymbopogon nardus dominated grasslands, often demarcated by native forests, are the most vulnerable. The present study quantified the soil seed bank and the standing vegetation of these highly invaded grasslands. Forest-grassland edge (FGE) has been identified as the starting point for this invasion, and therefore sampling was carried out twice at different distances from the FGE towards the grassland $(0,10$ and $30 \mathrm{~m}$ ). The soil seed bank showed high seasonality with higher abundance and richness in the wet season than in the dry season. Interestingly, the dry season soil seed bank was dominated by native species $(78 \%)$ while the wet season seed bank was dominated marginally by exotics $(52 \%)$, with the highest contribution from Austroeupatorium. The scarcity of tree seedlings was noticed during the study. Austroeupatorium and tree seeds showed decreasing trends from the FGE towards the invasive grassland, and were evident in the seed bank as well as in the standing vegetation. Despite similar trends, the soil seed bank and the standing vegetation of invasive grasslands showed low similarity in terms of richness and abundance due to the dominance of a single species. The results suggest that Austroeupatorium invasion has the potential to alter the existing vegetation in these highly degraded grasslands and influences their succession over time.
\end{abstract}

Keywords: soil seed bank, forest-grassland edge, anthropogenic grasslands, Knuckles Conservation Area, Sri Lanka.

\section{INTRODUCTION}

Invasive plants usually produce large number of seeds to facilitate their spread (Richardson et al., 2011). As a result, plant invasions alter the existing soil seed bank with the potential of altering the vegetation over time. Therefore, information on how plant invasions change the structure and composition of resident soil seed banks can provide some valuable intuition into long-term impacts of plant invasions. Impacts of invasive plants cannot be generalized as they depend on the species as well as its introduced habitat. To relate the impacts of plant invasion to resident communities and ecosystem functions, the information on soil seed banks is crucial (Gioria and Osborne 2010, Gioria et al., 2011). The details of the soil seed bank in invaded habitats are also vital to introduce control measures to manage and mitigate their impacts (Cox and Allen, 2008; Abreu et al., 2014).

The soil seed bank is an aggregation of viable seeds found in the soil (Baker, 1989; Gomaa, 2012). The structure and the composition of the soil seed bank can reflect the future of the community over changing environmental conditions as well as a record of the previous plant community in the site (Coffin and Lauenroth 1989; van der Valk and Pederson, 1989; Auld and Denham, 2006). Therefore, soil seed bank provides an important source of information in restoration efforts of invaded habitats (Bakker et al., 1996; Thompson et al., 1997; Pärtel et al., 1998; Grime, 2001). However, more attention has been drawn towards exploring the ecological impacts of invasive plants on the resident communities with less emphasis on soil seed banks (Gioria et al., 2012).

Over the last decade, Austroeupatorium inulifolium is aggressively invading many land use types in the Knuckles Conservation Area (KCA) in Sri Lanka. Out of the many natural and semi-natural land use types found in KCA, highly degraded, Cymbopogon nardus dominated anthropogenic grasslands seem to be the most vulnerable for this shrub invasion. In KCA, these highly invaded grasslands are often 
bordered by species-rich lower montane forest patches. The edge between the forest and the grassland is clearly demarcated and seems to act as the starting point for Austroeupatorium invasion towards the open grassland. In the present study, we hypothesize that the shrub invasion has the potential to alter the structure and the composition of the soil seed bank. In addition, the study also hypothesizes that the similarity between the soil seed bank and the standing vegetation is minimal in spite of singlespecies dominance.

\section{MATERIALS AND METHODS}

\section{Description of the study area}

The study was carried out in anthropogenic grasslands in KCA, which is located in the central highlands (Wet Zone) of Sri Lanka. The mean annual temperature in the area is $26{ }^{\circ} \mathrm{C}$, which can vary between $18.5{ }^{\circ} \mathrm{C}$ and $21^{\circ} \mathrm{C}$, depending on the altitudinal variations (Cooray, 1998). The mean annual rainfall varies from $2,540 \mathrm{~mm}$ on the eastern side to $3,810-5,080$ $\mathrm{mm}$ on the rest of the massif (Cooray, 1998), and receives rainfall from both monsoons due to its strategic position facing respective wind currents (Werner, 1982). During the colonial period, most of the lower montane forests in the area have been cleared to establish tea and coffee plantations. However, after so many years under plantations, some of them have been abandoned later on due to low productivity and diseases. With time, these abandoned plantations have been slowly transformed into Cymbopogon nardus dominated grasslands. These grasslands remain as it is for the last 3-4 decades, with no sign of natural succession in spite of being demarcated by lower montane forest patches.

\section{Test Species}

Austroeupatorium inulifolium (Kunth) R.M. King and H. Rob is a shrub belongs to the family Asteraceae. It is a native of Tropical South America, and later introduced in Sumatra and Java (Dasanayake, 1994-1995). The shrub grows up to $1-5 \mathrm{~m}$ in height, with opposite leaves showing deltoid-ovate, petiolate and gradually acuminate at the apex. Inflorescences are creamy white in colour. Flowering occurs mainly in August. Fruit is an achene (Dasanayake, 19941995). The shrub grows well in the open or under partial shade, but not in the forest interior (McFadyen, 2003). Austroeupatorium has been first identified in Sri Lanka in mid 1990s but noted as a common plant along roadsides at mid elevations. In spite of its well know invasive nature in other countries, Austroeupatorium has been identified as an invasive plant in Sri Lanka fairly recently.

\section{Enumeration of the soil seed bank}

Composite soil samples were collected using 25 $\mathrm{cm} \times 25 \mathrm{~cm}$ wooden quadrats to a depth of $5 \mathrm{~cm}$ (after removing the surface litter) from three different distances away from the forestgrassland edge $(0,10$ and $30 \mathrm{~m})$ towards the invasive grassland, totaling 36 soil samples (3 transects $\times 3$ distances $\times$ four representative sites). Soil samples were then laid on plastic trays $(20 \mathrm{~cm} \times 20 \mathrm{~cm})$ containing $1.5 \mathrm{~cm}$ deep sterilized sand layer and were kept in a shade house. The soil trays were watered as required. The emerging seedlings were tagged, counted and identified initially into different morphospecies. Initially, the seedling emergence was monitored daily but later every 2-3 days depending on the rate of seedling emergence. The seedlings were thinned to avoid any shading effect. The seedlings that were difficult to identify transferred into separate plastic pots to facilitate identification. When the seedling emergence slowed down, the soils were mixed and rewetted. The seedling emergence was monitored until no more seedlings emerged (approximately 13 - 14 weeks). Two soil samplings were carried out to represent wet and dry seasons (May, 2014 and September, 2014, respectively).

\section{Enumeration of the standing vegetation}

The standing vegetation was enumerated (only once) in same sites used to enumerate the soil seed bank. Three, $2 \mathrm{~m} \times 2 \mathrm{~m}$ quadrats were demarcated (5 $\mathrm{m}$ apart from each other) at each distance $(0,10$ and $30 \mathrm{~m}$ distances away from the forest-grassland edge) and the vegetation (less than $1 \mathrm{~m}$ in height) was enumerated and identified to their species levels. The vegetation was categorized into different life forms (tree, shrub, herb and graminoids) with climbers categorizing under herbs. Ecological status of the identified species (native, endemic and exotic) was verified using the species guides available. Invasive, introduced and naturalized exotics were all categorized as exotics.

Species diversity (Shannon Weiner's Index), species richness (Margalef's Index) and evenness indices (Pielou's Index) were 
calculated according to Magurran (1988). The percentage contribution of each species to the soil seed bank was determined. Seed abundance was given as the mean number of observed germinants and seed density was calculated by dividing the observed germinants by the total area of a soil sample $\left(0.1875 \mathrm{~m}^{2}\right)$ and presented as per square meter basis.

\section{Data analysis}

Descriptive statistics were carried out using Microsoft Excel 2010 to visualize any interesting patterns between distances and seasons. Parametric statistics were carried out using Minitab 17.1 software. The data taken from wet and dry soil seed banks were first analyzed for different distances separately using one-way ANOVA. After identifying morphotypes into different life forms (grasses, herbs, shrubs and trees) and ecological status (exotic, native and endemics), the data were re-analyzed using Generalized Linear Model (GLM) considering the seasons (wet and dry season) and distances $(0, \quad 10$ and $30 \mathrm{~m})$ as fixed factors. Correspondingly, the standing vegetation data was analyzed using one-way ANOVA with pairwise ranking to observe any significant differences between means. Post-hoc Tukey's tests $(\alpha=0.05)$ were carried out to compare means. Data were tested for normality of distribution prior to carryout parametric statistical analysis and as necessary data were transformed to meet the assumptions of ANOVA. The number of germinants, those died before identifying them into morphospecies/species, was removed from the analysis.

\section{RESULTS}

\section{Soil Seed Bank}

\section{Composition of the soil seed bank}

A total of 2,214 germinable seeds were recorded belonging to 44 species and 21 families in the dry season. The highest density of total viable seeds was observed at $0 \mathrm{~m}$ distance (FGE) which decreased towards the open grassland. The dry season soil seed bank was dominated by native species (78\%) followed by exotics (introduced/invasive) (18\%) and endemics (5\%) (Table 1). The dry season soil seed bank also consisted of $41 \%$ herbs, $36 \%$ grasses, $22 \%$ shrubs and $<1 \%$ trees. In the wet season, a total of 3,825 germinable seedlings were counted belonging to 61 species and 22 families. In contrast to the dry season, the wet season soil seed bank was dominated marginally by exotics (52\%), mainly by Austroeupatorium, which followed by natives (36\%) and endemics (12\%). Among the germinable seedlings, 53\% are shrubs, $30 \%$ grasses, $15 \%$ herbs and $<1 \%$ trees were recorded. In the wet season, Austroeupatorium seeds dominated the soil seed bank (47\%) followed by Osbeckia octandra, a known endemic species.

In both seasons, the densities of shrub and tree seeds declined towards the invasive grassland with grasses and herbs showing an increasing trend along the same transect (Table $1)$. The scarcity of tree seeds was common in all distances. The only tree species observed in dry season soils was Acronychia pedunculata (Rutaceae), a known pioneer tree species, was recorded only in the FGE. Shrub density was significantly higher at the FGE $(0 \mathrm{~m})$ compared to other distances in both seasons (ANOVA: wet and dry: $\mathrm{P}<0.001, \mathrm{DF}=2$ ). Tree seeds too showed a significantly higher abundance at FGE in the wet season compared to the dry season (ANOVA: $\mathrm{P}=0.003, \mathrm{DF}=3$ ). A similar trend was also noted in the dry season, though not significant.

The density of exotic seeds (including Austroeupatorium) decreased sharply towards the open, invasive grasslands (at $\mathrm{p}<0.001$ ) while endemics increased, the trend common to both seasons. However, the natives did not show any significant differences in densities between wet and dry seasons, but exotics were markedly higher in all distances during the wet season compared to that in the dry season (ANOVA: $\mathrm{P}=$ $0.001, \mathrm{DF}=3$ ). 
Table 1: Density of germinable seeds $\left(\right.$ per $\mathrm{m}^{2}$ ) at $0 \mathrm{~m}, 10 \mathrm{~m}$ and $30 \mathrm{~m}$ distances away from the forest-grassland ecotone (FGE). Significant differences between distances and seasons are indicated using superscript letters for different life forms and ecological status, separately.

\begin{tabular}{|c|c|c|c|c|c|c|}
\hline & \multicolumn{3}{|c|}{ Dry season } & \multicolumn{3}{|c|}{ Wet season } \\
\hline & $\mathbf{0 ~ m}$ & $10 \mathrm{~m}$ & $30 \mathrm{~m}$ & $\mathbf{0 ~ m}$ & $10 \mathrm{~m}$ & $30 \mathrm{~m}$ \\
\hline \multicolumn{7}{|l|}{ Life form } \\
\hline Herbs & $40.9^{\mathrm{a}}$ & $46.5^{\mathrm{a}}$ & $59.1^{\mathrm{a}}$ & $33.4^{\mathrm{a}}$ & $28.5^{\mathrm{a}}$ & $48.2^{\mathrm{a}}$ \\
\hline Grasses & $31.5^{\mathrm{a}}$ & $45.9^{\mathrm{a}}$ & $51.4^{\mathrm{a}}$ & $76.9^{\mathrm{a}}$ & $71.3^{\mathrm{a}}$ & $72.6^{\mathrm{a}}$ \\
\hline Shrubs & $69.2^{\mathrm{b}}$ & $9.8^{\mathrm{c}}$ & $5.1^{\mathrm{c}}$ & $236.3^{\mathrm{a}}$ & $66.0^{\mathrm{b}}$ & $80.3^{\mathrm{b}}$ \\
\hline Trees & $0.2^{\mathrm{b}}$ & $0.0^{\mathrm{b}}$ & $0.0^{\mathrm{b}}$ & $2.1^{\mathrm{a}}$ & $1.1^{\mathrm{ab}}$ & $0.8^{\mathrm{ab}}$ \\
\hline \multicolumn{7}{|l|}{ Status } \\
\hline Exotics & $46.9^{\mathrm{b}}$ & $11.4^{\mathrm{c}}$ & $5.6^{\mathrm{c}}$ & $215.3^{\mathrm{a}}$ & $70.5^{\mathrm{b}}$ & $84.4^{\mathrm{b}}$ \\
\hline Endemics & $2.3^{\mathrm{c}}$ & $5.1^{\mathrm{c}}$ & $8.6^{\mathrm{bc}}$ & $14.6^{\mathrm{bc}}$ & $32.3^{\mathrm{ab}}$ & $46.1^{\mathrm{a}}$ \\
\hline Native & $92.6^{\mathrm{ab}}$ & $85.3^{\mathrm{ab}}$ & $101.3^{\mathrm{ab}}$ & $118.7^{\mathrm{a}}$ & $64.1^{\mathrm{b}}$ & $71.3^{\mathrm{b}}$ \\
\hline
\end{tabular}

Table 2: Shannon-Weiner's diversity index, Sorenson's similarity Index [calculated with (+Aus) or without (Aus) Austroeupatorium] of soil seed banks at 0,10 and $30 \mathrm{~m}$ distances away from the forest grassland edge (FGE).

\begin{tabular}{lllllllllll}
\hline & \multicolumn{3}{c}{\begin{tabular}{l}
\multicolumn{2}{c}{ Shannon- Weiner's } \\
Index
\end{tabular}} & \multicolumn{3}{c}{ Margalef Index } & \multicolumn{3}{c}{ Evenness } \\
\hline Distance $(\mathrm{m})$ & & $\mathbf{0}$ & $\mathbf{1 0}$ & $\mathbf{3 0}$ & $\mathbf{0}$ & $\mathbf{1 0}$ & $\mathbf{3 0}$ & $\mathbf{0}$ & $\mathbf{1 0}$ & $\mathbf{3 0}$ \\
\hline \multirow{2}{*}{ Wet season } & + Aus & 1.80 & 2.31 & 1.98 & 8.71 & 7.43 & 5.84 & 0.46 & 0.63 & 0.57 \\
& - Aus & 2.79 & 2.62 & 2.09 & 10.11 & 7.94 & 6.19 & 0.71 & 0.72 & 0.61 \\
\hline \multirow{2}{*}{ Dry season } & + Aus & 2.47 & 2.52 & 2.08 & 6.26 & 6.70 & 5.26 & 0.71 & 0.73 & 0.64 \\
& - Aus & 2.41 & 2.48 & 2.08 & 6.26 & 6.49 & 5.06 & 0.70 & 0.72 & 0.65 \\
\hline
\end{tabular}

In the wet season, shrubs dominated the soil seed bank at FGE $(68 \%)$, with Austroeupatorium inulifolium dominating both 0 and $30 \mathrm{~m}$ distances, while Cyperus rotundus (Cyperaceae) was more abundant at $10 \mathrm{~m}$. The tree species observed included Cipadessa baccifera (Meliaceae), Maesa indica (Myrsinaceae), Wendlandia bicuspidata (Rubiaceae), Rauvolfia verticillata (Apocynaceae), Litsea gardneri (Lauraceae) and Symplocosco chinchinensis (Symplocaceae), where comparatively low tree seedlings abundance in both 10 and $30 \mathrm{~m}$ distances.

From the total number of species recorded in the dry season soil seed bank, 18 species (31\%) were recorded in all distances, while 17 species $(\approx 29 \%)$ found exclusively in the FGE and 3 species each $(\approx 5 \%)$ in 10 and $30 \mathrm{~m}$ distances. In the wet season, 16 species $(\approx$ $39 \%$ ) were common to all distances, and five, three and two species $(\approx 12,7$ and $5 \%$ ) recorded exclusively in FGE, 10 and $30 \mathrm{~m}$, respectively.

\section{Diversity of the soil seed bank}

The Shannon-Weiner diversity indices of the soil seed bank were calculated with or without Austroeupatorium (+Aus and -Aus; Table 2). In the wet season, diversity indices showed lower values with Austroeupatorium (+Aus), while in the dry season no such effect was noted. The diversity and richness indices decreased towards the invasive grassland from the FGE irrespective of Austroeupatorium present/absent in the analysis. All diversity and evenness indices were higher at all distances when Austroeupatorium was excluded from the analysis (-Aus) indicating its dominance in the soil seed bank. However, this impact is less in the dry season, due to lower abundance of Austroeupatorium seeds in the dry season soil seed bank than that in the wet season. 


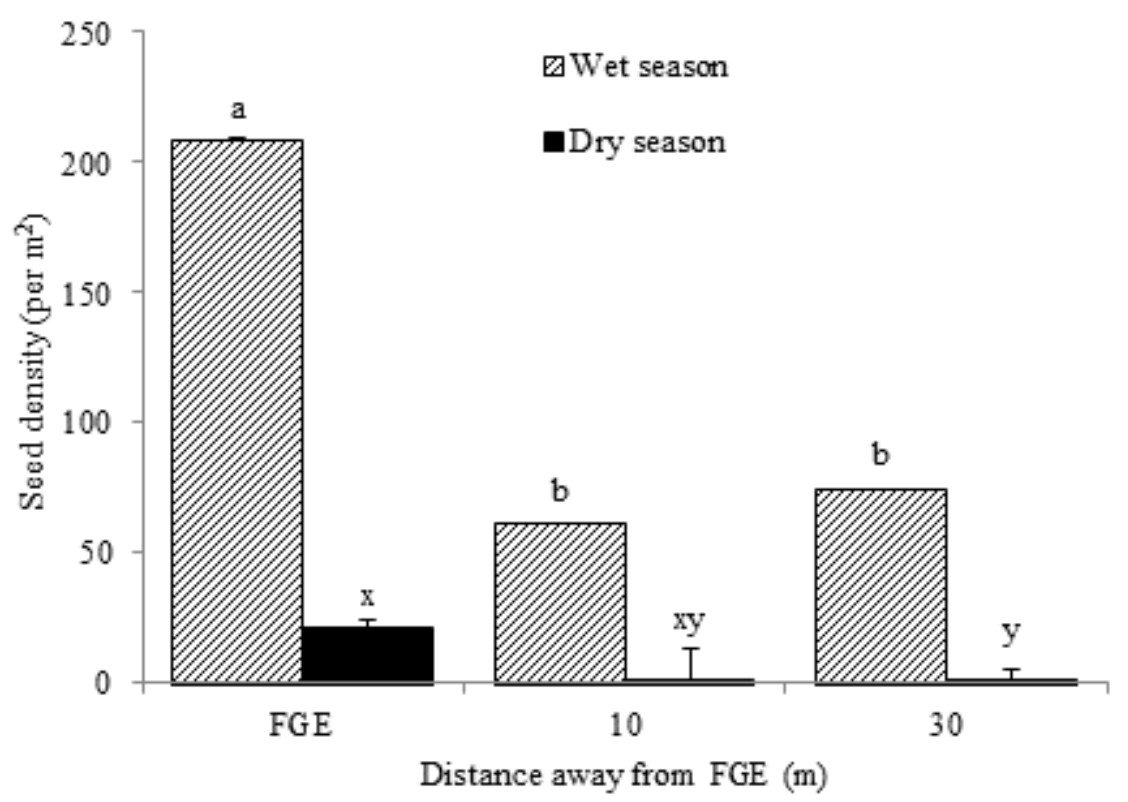

Figure 1: The density of Austroeupatorium inulifolium seeds recorded during wet and dry season soil seed banks at forestgrassland edge $(0 \mathrm{~m})$ and 10 and $30 \mathrm{~m}$ distances away from the FGE towards the open grassland. Vertical bars represent standard error of the mean (SEM). Different letters indicate significant differences between distances.

\section{Contribution of Austroeupatorium inulifolium}

The density of Austroeupatorium seeds was significantly higher in the wet season than in the dry season, and this difference was evident in all distances (Figure 1). The highest density of Austroeupatorium seeds was recorded in the FGE, and the density declined sharply towards the grassland.

The figure 2 depicts the cumulative number of germinable and Austroeupatorium seeds at different distances along the forestgrassland transect in wet and dry seasons, during the incubation period. In dry season soils, Austroeupatorium seeds were noticeably less compared to the wet season. This was true with total germinable seeds as well. Germinable seeds including Austroeupatorium declined sharply from the forest-grassland edge towards the grassland. This trend was noted in both seasons, with more conspicuous decline in the wet season.

\section{Standing vegetation}

\section{Composition}

A total of 109 species $(71,56$ and 52 species at 0,10 and $30 \mathrm{~m}$, respectively) were recorded during the vegetation survey, of which 21 species
(19\%) were found in all distances. The study also recorded 33, 11 and 16 species $(30,10$ and $15 \%$ ) unique to distances 0,10 and $30 \mathrm{~m}$, respectively.

The densities of trees and shrubs were significantly higher at the FGE $(\mathrm{P}<0.000)$, and declined towards the open grassland (Table 3; Figure 3). The trees were the least abundant in all distances compared to other life forms (Table 3 ). The standing vegetation was dominated by native species $(70 \%)$ followed by exotics $(20 \%)$ and endemics (10\%). The FGE $(0 \quad \mathrm{~m})$ demonstrated higher density of native plants with a decreasing trend towards the open grassland. Symplocos cochinchinensis (Symplocaceae), Eugenia bracteata (Myrtaceae), Pedilanthus reticulatus (Euphorbiaceae), Cleistocalyx nervosum (endemic, Myrtaceae), Macaranga peltata (Euphorbiaceae), Cipadessa baccifera (Meliaceae), Rauvolfia densiflora (Apocynaceae), Wendlandia bicuspidata (Rutaceae) are some of the tree species recorded in the study. 


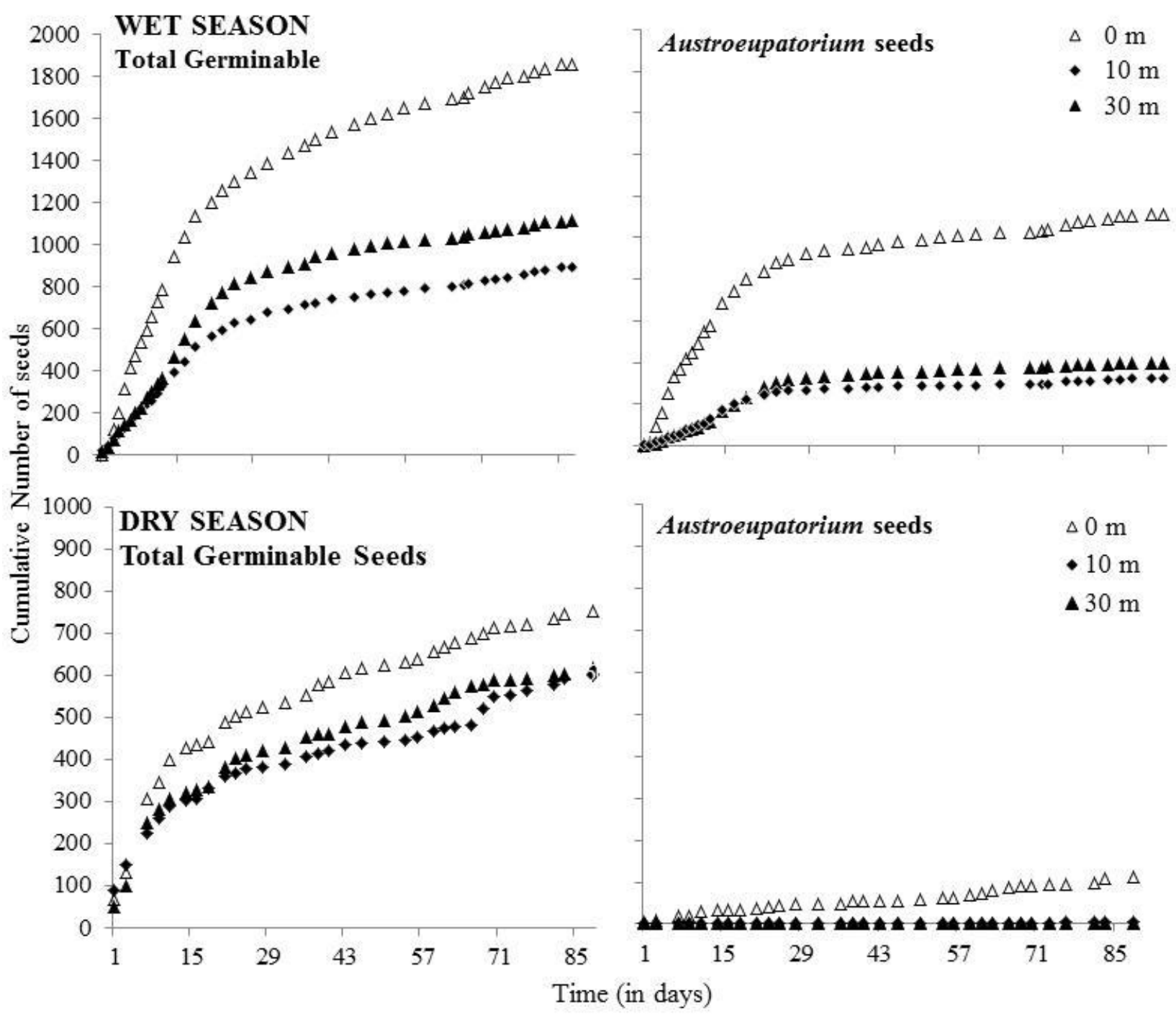

Figure 2: The cumulative number of germinable seeds of Austroeupatorium inulifolium and total number of seeds over the incubation period at different distances away from the forest-grassland ecotone (FEG, $10 \mathrm{~m}$, and $30 \mathrm{~m}$ ) in wet and dry season soil samples. Seedling emergence was monitored for nearly three months.

Table 3: The density (per $\mathrm{m}^{2}$ ) of the standing vegetation at $0 \mathrm{~m}, 10 \mathrm{~m}$ and $30 \mathrm{~m}$ distances away from the forest grassland edge (FGE); significant differences between distances are indicated for different life forms and ecological status separately using superscript letters.

\begin{tabular}{lccc} 
& \multicolumn{3}{c}{ Density of standing vegetation $/ \mathbf{m}^{\mathbf{2}}$} \\
\cline { 2 - 4 } Life form & $\mathbf{0 ~ \mathbf { ~ }}$ & $\mathbf{1 0 ~ \mathbf { ~ }}$ & $\mathbf{3 0 ~} \mathbf{~}$ \\
Herbs & $9.9^{\mathrm{a}}$ & $13.4^{\mathrm{a}}$ & $12.3^{\mathrm{a}}$ \\
Grasses & $7.6^{\mathrm{a}}$ & $6.0^{\mathrm{a}}$ & $3.3^{\mathrm{a}}$ \\
Shrubs & $12.7^{\mathrm{a}}$ & $4.2^{\mathrm{b}}$ & $3.1^{\mathrm{b}}$ \\
Trees & $4.6^{\mathrm{a}}$ & $0.8^{\mathrm{b}}$ & $0.5^{\mathrm{b}}$ \\
\hline & & & \\
Status & & & $4.25^{\mathrm{a}}$ \\
Exotics & $6.00^{\mathrm{a}}$ & $5.83^{\mathrm{a}}$ & $2.60^{\mathrm{a}}$ \\
Endemics & $1.92^{\mathrm{a}}$ & $3.63^{\mathrm{a}}$ & $12.40^{\mathrm{b}}$ \\
Native & $26.94^{\mathrm{a}}$ & $14.98^{\mathrm{b}}$ & \\
\hline
\end{tabular}


Though it was not significant at $\alpha=0.05$, there was an increasing trend of the abundance of seedlings at the FGE and then declined towards the open grassland. In contrast, saplings also showed a similar trend from FGE towards the open grassland invaded by Austroeupatorium (Figure 4).

\section{Diversity}

The diversity and richness indices decreased from the FGE towards the grassland, irrespective of the presence or absence of Austroeupatorium in the analysis (Table 4). However, indices showed higher values +Aus than that of - Aus.

\section{Contribution of Austroeupatorium inulifolium}

The abundance of Austroeupatorium was significantly higher at the FGE (total, $\mathrm{P}<0.01$; seedling, $\mathrm{P}<0.01$; sapling, $\mathrm{P}<0.01$ ), then decreased towards the open grassland (Figure 4). Austroeupatorium contribution to the standing vegetation was $13 \%, 9 \%$ and $10 \%$ at $0 \mathrm{~m}, 10 \mathrm{~m}$ and $30 \mathrm{~m}$ distances, respectively.

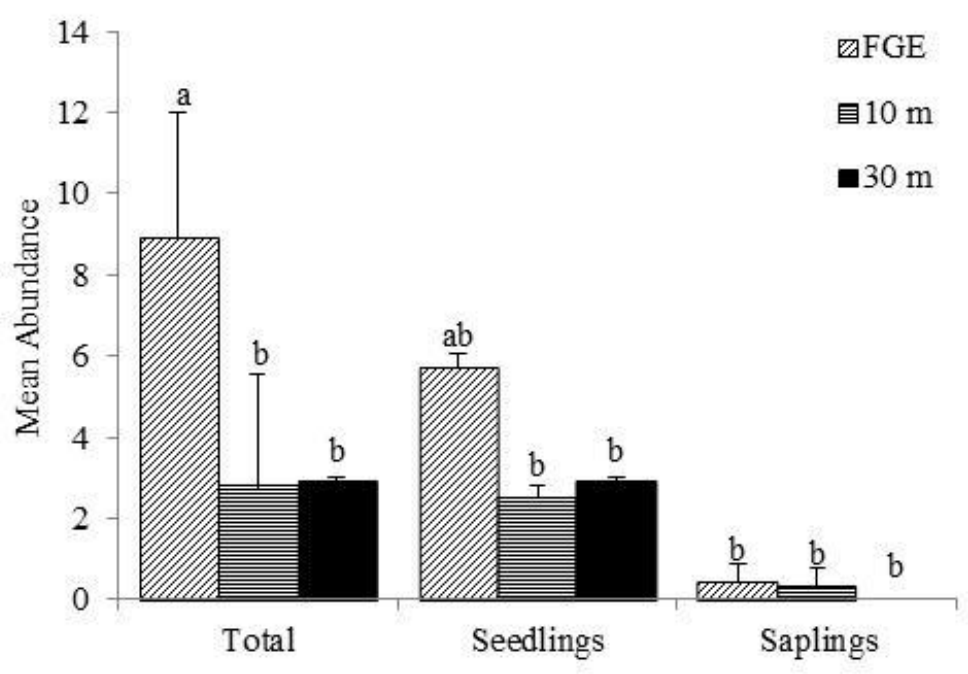

Figure 3: Mean abundance of tree individuals [seedlings < than $0.5 \mathrm{~m}$; saplings < than $2 \mathrm{~m}$ and mature $>2 \mathrm{~m}$ in height] from the forest-grassland edge (FGE) towards the grassland. Vertical bars represent standard error of the mean (SEM).

Table 4: Diversity (Shannon-Weiner's index), species richness (Margalef's Index), evenness (Pileou's index) of standing vegetation (indices calculated with and without Austroeupatorium inulifolium) at $0 \mathrm{~m}, 10 \mathrm{~m}$ and $30 \mathrm{~m}$ distances away from the forest grassland edge (FGE).

\begin{tabular}{llllllllll}
\hline & \multicolumn{3}{l}{$\begin{array}{l}\text { Shannon- Weiner's } \\
\text { Index }\end{array}$} & & \multicolumn{2}{c}{ Margalef's Index } & \multicolumn{3}{c}{ Pileou's index } \\
\hline Distance (m) & $\mathbf{0}$ & $\mathbf{1 0}$ & $\mathbf{3 0}$ & $\mathbf{0}$ & $\mathbf{1 0}$ & $\mathbf{3 0}$ & $\mathbf{0}$ & $\mathbf{1 0}$ & $\mathbf{3 0}$ \\
\hline+ Aus & 4.08 & 3.84 & 3.77 & 17.6 & 15.7 & 15.2 & 0.96 & 0.95 & 0.95 \\
\hline- Aus & 3.14 & 3.06 & 2.69 & 20.5 & 17.1 & 18.5 & 0.74 & 0.76 & 0.68 \\
\hline
\end{tabular}




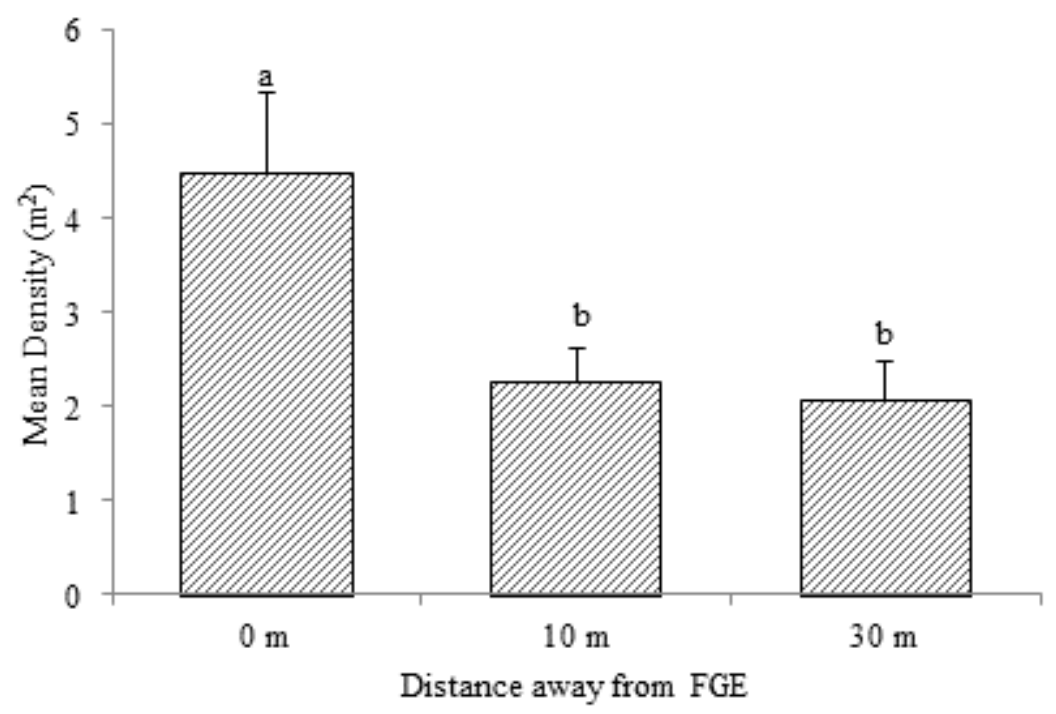

Figure 4: Total (mature plants, seedlings and saplings), seedlings and saplings abundance of Austroeupatorium inulifolium in the standing vegetation at different distances starting from the forest-grassland edge $(0 \mathrm{~m})$ and $10 \mathrm{~m}$ and $30 \mathrm{~m}$ away from the FGE towards the open grassland. Vertical bars represent standard error of the means (SEM).

\section{DISCUSSION}

Many studies have been conducted to evaluate the changes in the standing vegetation following invasions (Gaertner et al., 2009; Gioria and Osborne, 2010), with comparatively less attention below-ground aspects, probably due to practical difficulties. The present study evaluated the composition of the soil seed bank in these highly invaded grasslands, and compared with that of the standing vegetation.

The soil seed bank of these highly invaded grasslands showed seasonal differences in terms of composition, abundance and diversity. The germinable seeds were lesser in the dry season, whereas tree and shrub seeds were higher in the wet season. However, compared to other life forms, lack of tree seeds was prevalent in all distances in both seasons. Despite the presence of a seed source nearby, the dearth of tree seeds in grasslands may be due to their poor dispersal power or else due to their inherent long dormancy periods (Gomaa, 2012), which is a common trait among tree seeds. In a study carried out previously, scarcity of tree seeds has been identified as a major constraint for the lack of natural succession in these highly invasive grasslands at KCA (Gunaratne et al., 2011). Despite the presence of mature individuals of pioneer tree species such as Symplocus cochinchinensis and Macaranga indica in the periphery of these grasslands, no seedlings have been recorded in the soil seed bank. Symplocus cochinchinensis seeds are known to exhibit physiological and epicotyl dormancy (Athugala et al., 2014), perhaps explaining the present results. The absence of dormancy breaking cues or phenological events during the study period may have led to these findings. Fowler (2012) noted that the short incubation period (3-4 months in the present study) may be considered as a drawback in establishing the actual composition of the soil seed bank. However, a longer duration of incubation period may be beneficial to examine the diversity and compositional trends further.

The dry season soil seed bank was dominated by native species while the exotics dominated in the wet season, indicating clear seasonal differences. A substantial contribution of native seeds in an invaded soil seed bank can therefore be considered as an indication of relatively low impact of the invader, despite the above-ground vegetation is highly invaded (Abella et al., 2012). It also can be considered as an indication that the invaded community may recover once the invader is excluded from the system. However, a conflicting situation was observed during the wet season, where the exotics (mainly the Austroeupatorium) dominated the soil seed bank (47\%). In favour, previous studies too have shown instances where a single species dominates the soil seed bank of invaded communities, at times contributing more than $70 \%$ of the soil seed bank (Herrera and Nassar, 2009; Gioria and Osborne, 2010; Gioria and Pysek, 2016). However, the studies also revealed that a large seed bank is not essential 
always for successful invasion (Gioria and Pysek, 2016). Low contribution of seeds of invasive species in heavily invaded communities has been recorded in vegetation where the invader has been present for a long period of time (Shen et al., 2006; Fisher et al., 2009; Gioria and Osborne, 2010).

Higher species diversity and richness was observed in both wet and dry seed banks along the forest-grassland edge and then decreased towards the open, invaded grasslands. The results indicate that more species tend to colonize in the FGE due to more favourable micro-climatic conditions following the invasion. Laurance et al., (2007) suggest that the changes in an ecotone may influence the regeneration of degraded grasslands by changing species diversity and composition, community dynamics and ecosystem functioning. Therefore, in spite of claims that species diversity decreases with invasion (Levine, 2003), the degraded habitats act differently to other natural/near natural habitats, showing positive impacts following the invasion. Field observations together with data from the present study indicated that Austroeupatorium prefers the FGE to colonize before spreading towards the grassland.

Austroeupatorium seeds were more abundant in the wet season indicating its high germination power as well as its timing of phenological events that take place during the height of the dry season. Austroeupatorium seeds dominated the wet season soil seed bank $(\approx$ $47 \%$ ), whereas the dominance in the dry season was rather less $(\approx 5 \%)$. Austroeupatorium normally flowers during the height of the dry season (July-August), and as a result higher abundance of seeds can become available in the soil during the wet season. The result suggests that the Austroeupatorium seeds can remain in soils and start to germinate when the wet season arrives. Once the environmental conditions become favourable, Austroeupatorium may germinate quickly and grow faster compared to the other natives. Early and/or rapid germination is a common feature of invasive plants (Gioria et al., 2016). The results also showed a gradual decline in Austroeupatorium and tree seeds from the FGE towards the open grassland, indicating a facilitative effect of Austroeupatorium cover for the establishment of forest species in these degraded grasslands. Previous studies claimed that ecotones (spatial transition or boundary zone between two adjacent communities) are speciesrich due to favorable microhabitat conditions, which differ from the adjoining communities (Odum, 1971; Sharma et al., 2014). However, this occurrence cannot be generalized as a consistent feature among all ecotones that exist between different land use types (Kark and van Rensburg, 2006; Walker et al., 2003; Lloyd et $a l ., 2000)$. In favour of present findings, other studies too have shown a higher abundance of trees in edge environments as a result of higher establishment and survival rates than in open grasslands (Bossuyt et al., 2002; Honnay et al., 2001; Devlaeminck et al., 2005).

\section{Similarity between the soil seed bank and standing vegetation}

The soil seed bank and the standing vegetation showed similar trends in terms of abundance and richness across the forest-grassland transect (Table 5), where they both decreased with increasing distance from the FGE. However, the species richness was higher in the standing vegetation compared to the soil seed bank. Previous studies demonstrate that grasslands show high similarity between soil seed bank and the standing vegetation compared to forest ecosystems (Hopfensperger, 2007). However, there have been exceptional circumstances too (Kalamees and Zobel, 1998, Wagner et al., 2003), which could be attributed to overrepresentation of a single species in the soil seed bank, compared to the vegetation. This may be the scenario in the present study. However, the similarities between soil seed bank and standing vegetation could help the field officers to manage invasive species and understand the resilience of an ecosystem.

The standing vegetation too demonstrated a dearth of tree seedlings and saplings in these invasive grasslands. In a study carried out by Gunarathne et al., (2011), it was also noted that one or more of factors may affect the lack of tree species establishment in these grasslands thereby limiting the forest succession. They attributed the lack of tree seedlings in these grasslands to limiting soil resources, high competition from the grass matrix and lack of resilience to occasional fires. Rundel et al. (2013) also revealed that nutrient availability, temperature fluctuations, fire, herbivory and lack of soil mutualism can influence the species establishment and survival. 
Table 5. Species richness (numbers of species) and abundance (total number of plants) in wet and dry soil seed banks in comparison to the standing vegetation, at $0 \mathrm{~m}, 10 \mathrm{~m}$ and $30 \mathrm{~m}$ distances away from the forest grassland edge (FGE).

\begin{tabular}{lllllllllll} 
& \multicolumn{4}{c}{ Soil seed bank } & \multicolumn{3}{c}{ Standing vegetation } \\
\cline { 2 - 10 } & \multicolumn{3}{c}{ Dry Season } & \multicolumn{3}{c}{ Wet Season } \\
\cline { 2 - 10 } & FGE & $\mathbf{1 0} \mathbf{~ m}$ & $\mathbf{3 0} \mathbf{~ m}$ & FGE & $\mathbf{1 0} \mathbf{~ m}$ & $\mathbf{3 0} \mathbf{~ m}$ & FGE & $\mathbf{1 0} \mathbf{~ m}$ & $\mathbf{3 0} \mathbf{~ m}$ \\
\hline Species richness & 32 & 32 & 26 & 52 & 39 & 32 & 71 & 56 & 52 \\
Abundance & 142 & 102 & 116 & 826 & 396 & 478 & 53 & 39 & 29 \\
\hline
\end{tabular}

The standing vegetation too showed higher species richness and diversity along the FGE compared to other distances towards the open grassland. The favourable biotic and abiotic factors at the forest-grassland ecotone may have led to higher species richness and diversity. Among these factors, light intensity can be a key factor. The availability of light can influence the survival and growth of tree seedlings, with tree species showing low mortality in the absence of light during early life stages, but not homogeneously across different life stages (Kunstler et al., 2009). Furthermore, some seeds need certain light intensities to stimulate germination and therefore the light demanding species can establish along the forest borders (Aide and Cavelier, 1994; Espeland et al., 2010; Koncz et al., 2011). The results of the present study suggest that the canopy of the Austroeupatorium along the FGE seems to provide conditions favourable for tree seedlings to get establish and survive compared to the open grassland, which received high intensity of sun light throughout the day.

\section{CONCLUSION}

Despite low relative abundance of Austroeupatorium in the standing vegetation, its ability to produce a large number of seeds can make it an aggressive invader over time. The ability of Austroeupatorium seeds to germinate rather quickly further facilitates its invasive behaviour. Even non-dormant seeds like Austroeupatorium can remain in soil until proper environmental cues are met to stimulate the germination (Thompson, 2000). The present results suggest that Austroeupatorium has the potential to alter the composition of the existing grassland community over time with the help of its abilities to produce large number of seeds and germinate quickly. The study also confirmed that in spite of showing comparable trends, the similarity between the soil seed bank and the standing vegetation is minimal most possibly due to over-abundance of Austroeupatorium seeds in soil.

\section{REFERENCES}

Abella, S.R., Chiquoine, L.P. and Backer, D.M. (2012). Ecological characteristics of sites invaded by buffel grass (Pennisetum ciliare). Invasive Plant Science and Management 5: 443-453.

Abreu, R.C.R. De, Santos, F.F.D.M. and Durigan, G. (2014). Changes in plant community of Seasonally Semideciduous Forest after invasion by Schizolobium parahyba at southeastern Brazil. Acta Oecologica 54:57-64.

Aide, T.M. and Cavelier, J. (1994). Barriers to lowland tropical forest restoration in the Sierra Nevada de Santa Marta, Colombia. Restoration Ecology 2: 219-229.

Ashton, P.MS, Harris, P.G., Thadani, R. (1988). Soil seed bank dynamics in relation to topographic position of a mixed-deciduous forest in southern New England, USA. Forest Ecology and Management 111(1): 15-22.

Athugala, Y.S., Jayasuriya, K.M.G.G., Gunaratne, A.M.T.A. (2014). Seed Biology of Symplocos cochinchinensis towards reforestation of degraded submontane forests in Sri Lanka. Abs. Proceedings of the Postgraduate Institute of Science Research Congress, Sri Lanka: University of Peradeniya.

Auld, T.D., Denham, A.J. (2006). How much seed remains in the soil after a fire? Plant Ecol. 187:15-24.

Baker, H.G. (1989). Some aspects of the natural history of seed banks. In: Ecology of soil seed banks, ed. Leck, M.A., Parker, V.T. and Simpson, R.L. Academic Press, San Diego, CA, US, 9-21.

Bakker, J.P., Poschlod, P., Strykstra, R.J. et al. (1996). Seed bank and seed dispersal: important topics in restoration ecology. Acta Bot. Neerl. 45: 461-490.

Bossuyt, B., Heyn, M. and Hermy, M. (2002). Seed bank and vegetation composition of forest stands of varying age in central Belgium: consequences for regeneration of ancient forest vegetation. Plant Ecology 162: 33-48. 
Cox, R.D. and Allen, E.B. (2008). Composition of soil seed banks in southern California coastal sage scrub and adjacent exotic grassland. Plant Ecology 198:37-46.

Coffin, D.P., Lauenroth, W.K. (1989). Spatial and temporal variation in the seed bank of semiarid grassland. Am. J. Bot. 76: 53-58.

Fisher, J.L., Loneragan, W.A., Dixon, K. and Veneklaas, E.J. (2009). Soil seed bank compositional change constrains biodiversity in invaded species-rich woodland. Biological Conservation 142 (2): 256-269.

Fowler, W.M., (2012). Soil seed bank dynamics in transferred topsoil. B.sc. Thesis. Murdoc University.

Gaertner, M., Breeyen, A.D., Hui, C. and Richardson, D.M. (2009). Impacts of alien plant invasions on species rich- ness in Mediterranean-type ecosystems: a meta-analysis. Progress in Physical Geography 33:319-338.

Gioria, M., and Osborne, B. A. (2010). Similarities in the impact of three large inva- sive plant

species on soil seed bank communities. Biol. Invasions 12:1671-1683. doi: 10.1007/s10530009-9580-7.

Gioria, M., Dieterich, B., and Osborne, B. A. (2011). Battle of the giants: primary and secondary invasions by large herbaceous species. Biol. Environ. 3:177-193. doi: 10.3318/BIOE.2011.14

Gioria, M., Pyšek, P. and Moravcova, L. (2012). Soil seed banks in plant invasions: promoting species invasiveness and long-term impact on plant community dynamics. Preslia, 327-350.

Gioria, M., Pyšek, P. (2016). The Legacy of Plant Invasions: Changes in the Soil Seed Bank of Invaded Plant Communities. Bio Science 66 (1): 40-53.

Grime, J.P., Hodgson, J.G. \& Hunt, R. (1989). Comparative Plant Ecology. Chapman and Hall, London.

Grime, J.P. (2001). Plant strategies, vegetation processes, and ecosystem properties, $2^{\text {nd }}$ edn. Wiley, New York, NY, US.

Gomaa, N.H. (2012). Soil seed bank in different habitats of the Eastern Desert of Egypt. Saudi Journal of Biological Sciences 19: 211-220.

Gunaratne, A.M.T.A., Gunatilleke, C.V.S. and Gunatilleke, I.A.U.N. (2011). Release from root competition promotes tree seedling survival and growth following transplantation into humaninduced grasslands in Sri Lanka. Forest Ecology and Management 262: 229-236.

Herrera, I. and Nassar J.M. (2009). Reproductive and recruitment traits as indicators of the invasive potential of Kalanchoe daigremontiana (Crassulaceae) and Stapelia gigantea (Apocynaceae) in a Neotropical arid zone. Journal of Arid Environments, 73, 978-986.

Holmes, P.M. and Cowling, R.M. (1997). Diversity, composition and guild structure relationships between soil-stored seed banks and mature vegetation in alien plant-invaded South African fynbos shrublands. Plant Ecology 133:107-122.

Honnay, O., Verheyen, K. and Hermy, M. (2001). Permeability of ancient forest edges for weedy plant species invasion. Forest Ecology and Management 161:109-122.

Hopfensperger, K.N. (2007). A review of similarity between seed bank and standing vegetation across ecosystems. Oikos 116:1438-1448.

Kalamees, R. and Zobel, M. (1998). Soil seed bank composition in different successional stages of a species rich wooded meadow in Laelatu, western Estonia. Acta Oecologia 1: 175-180.

Kark, S. and Van Rensburg, B.J., (2006). Ecotones: marginal or central areas of transition?. Israel Journal of Ecology and Evolution 52 (1):29-53.

Koncz, G., Török, P., Papp, M., Matus, G. and Tóthmérész, B. (2011). Penetration of weeds into the herbaceous understorey and soil seed bank of a Turkey oak-sessile oak forest in Hungary. Community Ecology 12:227-233.

Kunstler G., Coomes D.A. and Canham C.D. (2009). Size-dependence of growth and mortality influence the shade tolerance of trees in a lowland temperate rain forest. Journal of Ecology 97: 685-695.

Laurance, W.F. (2007). Have we overstated the tropical biodiversity crisis? Trends in Ecology and Evolution 22:65-70.

Levine, J.M., Vila', M., D’Antonio. C.M., Dukes, J.S., Grigulis, K. and Lavorel, S. (2003). Mechanisms underlying the impacts of exotic plant Invasions. Proceedings of the Royal Society Biological Sciences 270:775-781.

Lloyd, K.M., McQueen, A.A., Lee, B.J., Wilson, R.C., Walker, S. and Wilson, J.B., (2000). Evidence on ecotone concepts from switch, environmental and anthropogenic ecotones. Journal of Vegetation Science 11 (6):903-910.

Magurran, A.E. (1988). Ecological diversity and its measurement. Princeton University Press, NJ, USA.

Odum, E.P., Odum, H.T. and Andrews, J., (1971). Fundamentals of ecology. Vol. 3. Philadelphia: Saunders.

Pärtel, M., Kalamees, R., Zobel, M. and Rosén, E. (1998). Restsration of species-rich limestone grassland communities from overgrown land: the importance of propagule avail- ability. Ecol. Engin. 10:275-286.

Richardson, D., Rejmánek, M. (2011). Trees and shrubs as invasive alien species - A global review. Diversity and Distributions 17 (5):788809.

Rundel, P.W., Dickie, I.A. and Richardson, D.M. (2013). Tree invasions into treeless areas: mechanisms and ecosystem processes. Biological Invasions 16:663-675. 
Shen, Y., Liu, W., Baskin, J.M., Baskin, C.C. and Cao, M. (2006). Persistent soil seed banks of the globally significant invasive species, Eupatorium adenophorum, in Yunnan Province, southwestern China. Seed science research 16 (2):157162.

Sharma, L.N., Vetaas, O.R., Chaudhary, R.P. and Måren, I.E. (2014). Ecological consequences of land use change: forest structure and regeneration across the forest-grassland ecotone in mountain pastures in Nepal. Journal of Mountain Science 11 (4):838-849.

Thompson, K., Bakker, J.P. and Bekker, R.M. (1997). The soil seed bank of North Western Europe: methodology, density and longevity. Cambridge University Press, Cambridge, UK.
Thompson, K. (2000). The functional ecology of seed banks. In: Seeds: The Ecology of Regeneration in Plant Communities. ed. M. Fenner, CAB International, Wallingford, UK, 215-235.

van der Valk, A.G., and Pederson, R.L. (1989). Seed banks and the management and restoration of natural vegetation. In: Ecology of soil seed banks, ed. M.A. Leck, V.T. Parker and R.L. Simpson, Academic Press, New York, 329-346.

Wagner, M. Poschlod, P. and Setchfield, R.P. (2003). Soil seed bank in managed and abandoned seminatural meadows in Soomaa National Park, Estonia. Annals of Botany Fennicy 40: 87 100.

Walker, T.S., Bais, H.P., Grotewold, E. and Vivanco, J.M. (2003). Root exudation and rhizosphere biology. Plant Physiology 132:44-51. 